\title{
Environmental management of coastal careers along the Doukkala-Abda linea
}

\author{
Toufik Remmal ${ }^{1, *}$, Halima Jounaid $^{1}$, and Fouad Amraoui ${ }^{1}$ \\ ${ }^{1}$ GAIA laboratory, UHIIC, FSAC, BP 5366, Maarif, Casablanca, Maroc
}

\begin{abstract}
This study proposes an environmental management model for sand and gravel quarries along the coastline from Doukkala to Abda. It aims at the one hand; the creation of a regional database bringing together all the quarries to identify and characterize the materials exploited as well as the major impacts and risks associated with subsequent physiographic changes; and on the other hand to develop intervention mechanisms to prevent, reduce or even eliminate the harmful effects of abusive exploitation on the environment and public safety, while taking into account the specificities of the region.
\end{abstract}

\section{Introduction}

The opening and exploitation of quarries on a national scale are experiencing considerable growth due to the real estate and tourism boom and the policy of major structuring projects (ports, dams, highways, etc.). Nevertheless, several problems are raised regarding their uncontrolled management and exploitation, which can cause significant damage to the environment. The current issue in the sector is to reconcile the economic necessities of the supply of materials and the requirements of the environmental approach following the principle of sustainable development.

For most careers opened before 2002, no real data on the careers was exploited, and no legislation applied. Currently, environmental impact studies are a necessary condition for authorization procedures. However, they do not imply that the measures recommended in the study are effective and controlled. On the other hand, while awareness of the problems of career management has given rise to a new law on the exploitation of quarries, it lacks implementing texts to regulate the exploitation of quarries effectively.

In this perspective, the present study, devoted to the coastal quarries of the Doukkala-Abda coastal line, falls (Fig. 1). It is a question of arriving at a reasoned and controlled management of these quarries while maintaining a balance between socio-economic development and preserving the environment, namely protecting landscapes, sites, and sensitive natural environments.

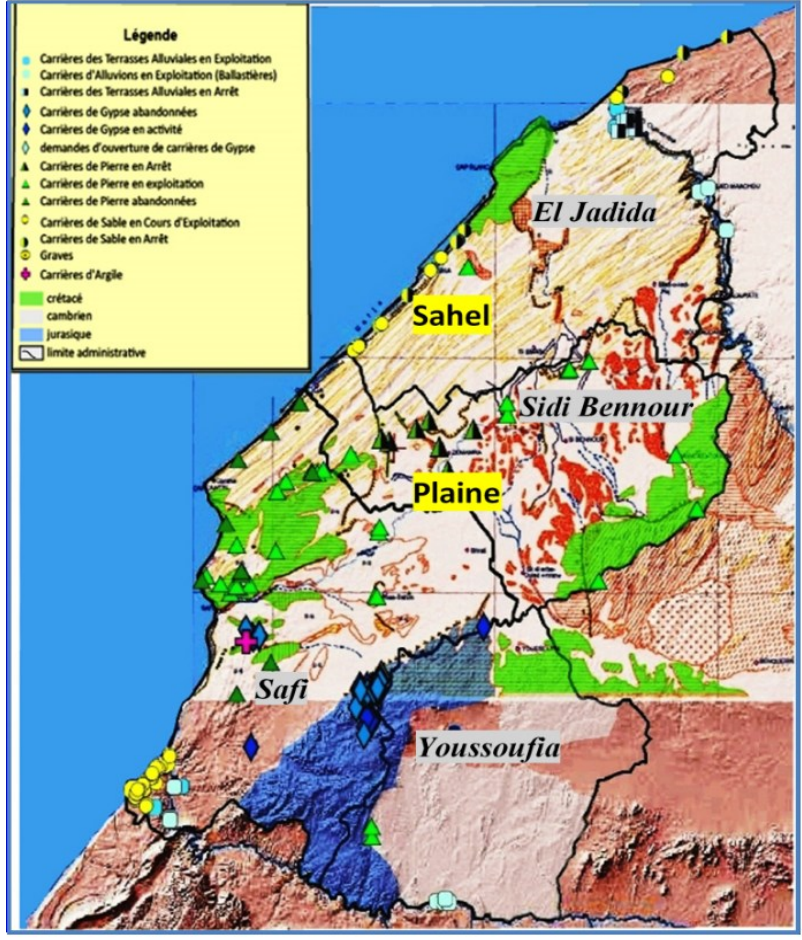

Fig. 1. The territorial distribution of inventoried quarries in the Doukkala-Abda provinces considers the region's geological and geomorphological structure.

\section{Methodology}

The approach undertaken consists of: i/ the constitution of a regional database necessary to identify and characterize the materials exploited, the quarry sites, the major impacts and the risks linked to physiographic modifications and ii/ the development of the mechanisms of intervention to prevent, reduce or even eliminate impacts on the environment and public safety while taking into account the specificities of the region. 


\section{Inventory and land use}

The region of Doukkala-Abda (DA) draws a set of approximately $7,700 \mathrm{~km} 2$, divided into two bands substantially parallel to the ocean [1]: The Sahel, endorheic coastal basin to the west, and the plain to the east (Fig. 1). The coastline stretches for about $350 \mathrm{~km}$, segmented into distinct morphological entities, including dune ridges locally flanked by marshes and mudflats, rocky cliffs with cliffs, beaches backed by stepped cliffs, and estuaries. The developments carried out on this shore respond, in general, to the socio-economic importance of the coastal zone in terms of urbanization, port infrastructure, processing industry, tourism, and fishing (Fig. 2).

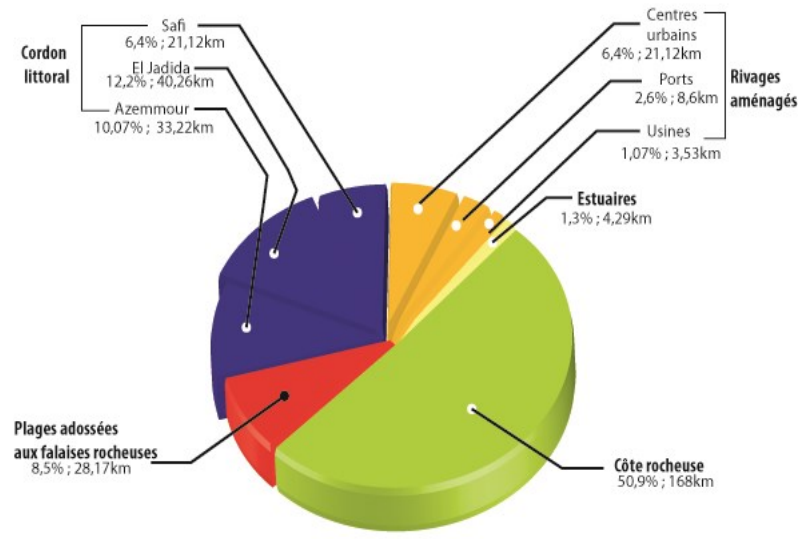

Fig. 2. According to the type of coast from Lamharza Essahel north of Azemmour to Lamaâchate south of Safi, distribution of the coastline is distributed according to the type of coast.

The histograms below (Fig. 3) show the distribution of quarries on the DA scale by category of materials, taking into account respectively the total volume authorized for mining and the overall surface area occupied by each type of quarry.
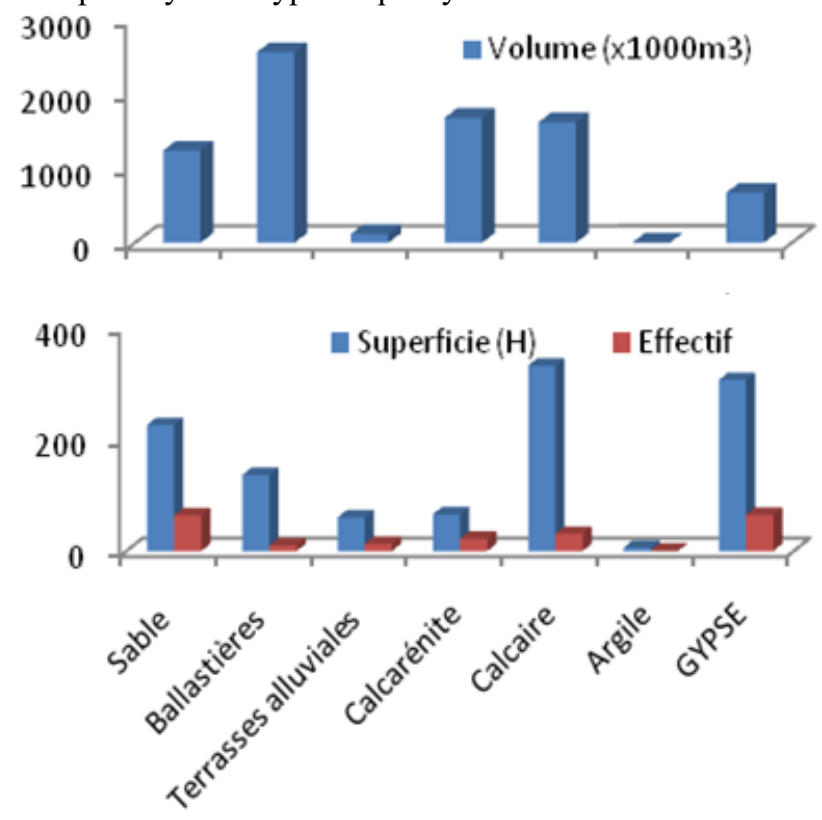

Fig. 3. Total area and volume authorized for extraction by category of material produced by the various quarries in the Doukkala-Abda region.
It emerges from this distribution that the land use by stone and sand quarries is higher correlatively to other materials. The limestone quarries show the greatest extension $(\sim 350$ hectares $)$ despite a small workforce, reflecting the extent of this material's quarry. In terms of volume, the ballast tanks provide the greatest production of substances useful for building and civil engineering work. They are the least numerous but settle on more than 120 hectares in the minor bed of the main river courses, namely Tensift and Oum Er Rbia. Sand exploitation exceeded $1.2106 \mathrm{~m}^{3}$, including more than $800,000 \mathrm{~m}^{3}$ on the Sahel Doukkala coast alone. In this sector, extraction is carried out directly in the dune ridge, in the middle of the maritime public domain.

\section{Major impacts due to the exploitation of quarries}

The major impact problems posed by the various quarries in the region and the risks due to the physiographic modifications of the sites were assessed according to the three categories of materials, namely: the sand of the littoral rim, alluvial material on the river beds Oum Rbia and Tensift and the rocky stones of Sidi Bennour, Youssoufia and the province of Safi.

\subsection{The sand quarries of the coastal barrier}

The sand bars along the coast are a natural barrier against sea and wind erosion. Excessive exploitation of coastal sand irreparably leads to a modification of the hydrodynamic balance and the morphogenetic profile of the coast due to a deficit of alluvial material.

Three phenomena are consequent to this exploitation: - The silting up of the land following the perforation of the coastal barrier and the disappearance of the plants that fix the sand at this level;

- Marine transgression, which leads to the replacement of the dune by seafronts;

- The washover phenomenon [2] is perceptible in the case of marshes and lagoons located behind the cordon, as in the classified Oualidia wetland. The increased erosion at the level of the lagoon causes a coastal drift, and the marsh risks being flooded by the burial of the lagoon silts under the deposits of marine sand, with the major consequence of the salinization of the water of the groundwater by mixing with the advancing seawater

\subsection{Alluvial quarries}

When the withdrawals from the stock of accumulated alluvial materials are greater than the inputs, the water line is lowered, which generates:

- Stream casing of the bed and destabilization of the banks by increasing their slope and undermining the base of the slope.

- Removal of engineering structures such as dams nearby.

- Decline of riparian vegetation by reduction of flood fields due to the lowering of the river bed. 
- Modification or removal of habitat due to the lowering of the stream. The backwaters, the secondary branches, or the valley bottom meadows become flooded less frequently or for a shorter period and thus lose their interest in the proper functioning of the fluvial ecosystem.

\subsection{Stone quarries}

The major impacts noted are mainly visual and landscape, which results from the often artisanal mode of exploitation:

- Steep excavations and fronts near settlements (Sidi Bennour).

- Risks of the collapse of galleries (Safi clay quarries),

- Stacking of slag heaps (Safi gypsum quarries),

- Excessive occupation of space by crushing stations and the development of traffic lanes

Destruction and denaturation of the initial environment made up of arable or wooded land, especially the impacts of the non-rehabilitation of exploited sites.

\section{Classification of operating sites}

The environmental risks were assessed for each category of materials through criteria considering the severity of the environmental impact, the sensitivity of the receiving environment (natural parks, crop fields, protected areas, etc.), and compliance with the regulations and environmental strategies and programs.

The analysis made it possible to classify quarry exploitation sites according to three categories:

\section{- Class 1: Areas prohibited for use}

These areas benefit from strong legal protection (drinking water catchment area, biological reserve, wetlands, etc.) or present major negative impacts that require closure and possible rehabilitation.

\section{- Class 2: Sensitive spaces.}

These are areas of recognized fragility requiring monitoring during operation and rehabilitation in the long term. The authorizations to open and operate these quarries must necessarily be accompanied by specific requirements adapted to the degree of interest and the constraints.

\section{- Class 3: Areas with minor issues}

They do not require special provisions and regulatory provisions and can be opened for exploitation without great prejudice to the environment.

\section{Regulatory aspects of quarrying}

Until 2017, the exploitation of quarries was governed by centuries-old and obsolete regulations: the Dahir of June 1914 , out of step with the new challenges and aspirations of the country. However, the legislator had initiated the first reform of this law in 2002, with Law $\mathrm{N}^{\circ}$. 08-01 relating to the exploitation of quarries, but which was not applied in the absence of the implementing texts. To remedy this situation, a circular from the Prime Minister was adopted in 2010, specifying, on a transitional basis, the procedures and modalities for the exploitation of quarries, pending the release of new regulations.

A new decree $\mathrm{N}^{\circ} 2-17-369$ implementing the law $\mathrm{N}^{\circ}$ 27-13 of 2015 relating to quarries was adopted, repealing the law of 1914. In detail, the draft decree includes provisions concerning the plans of quarry management, which will be broken down by region, with control of supply and demand and the cost of materials extracted from quarries. The definition of these quarry management plans will make it possible to locate the parts of the area where quarry exploitation cannot be authorized and to set the objectives to be achieved in terms of the redevelopment of quarry sites at the end of exploitation.

\section{Career management}

Despite the introduction of new regulations to put an end to a system perceived as unfair and favoring pensions and the informal sector, some aspects of fragility need to be removed:

The preeminence of the role of the supervisory administration, sometimes with a lack of clarity in interactions with the other departments concerned, reinforced by the absence of application texts and the multiplicity of references to other regulatory texts (regulations on the environment, regional planning, etc.); - Lack of treatment of the problem of dune sands (looting of beaches), the public forest domain, or the beds of wadis.

- Lack of treatment of the financial (non-harmonized pricing policy) and tax aspects in the text;

- Non-availability of the implementing texts of the law on essential elements such as opening requirements and content of the specifications, composition, and mode of operation of the national commission and the provincial commissions for monitoring the management of careers, level of bank guarantee, follow-up register, etc.

- Need for the availability of human capacities and control tools, at the national and local level;

- Data relating to quarries are, for the most part, scattered among the various administrative services and insufficient to assess production by the quarry and by material, the rate of redevelopment or rehabilitation of closed or abandoned quarries, etc. It is necessary to know precisely the quantities exploited and the forecasts of material needs at the regional and national level to define the major orientations of the regional plan for the rational management of the materials exploited while respecting environmental constraints.

\section{Rehabilitation of abandoned quarries}

The rehabilitation of abandoned quarries involves rehabilitation operations and post-exploitation redevelopment, namely:

- Secure the site

- Correct disharmony in the landscape due to the location in the middle of built-up areas or the case of sprawl 
- Provide a good environment by recreating a living environment adapted to the environment and consistent with the sector's development.

- Restore a vocation to the site (agricultural, forestry, industrial, tourist development)

While operations to restore and rehabilitate exploited quarries are the operator's responsibility, rehabilitation projects for abandoned quarries require consultation with all the partners concerned to adapt the sites to new uses by reconciling economic, environmental, and public safety aspects.

Thus, the identification of a quarry rehabilitation project requires a feasibility and impact study of the project, which must combine, on the one hand, a quality environmental approach and, on the other hand, meet the needs of economic development. Moreover, the social, of the municipality concerned and the wishes of the surrounding population.

Therefore, each rehabilitation project's financial, scientific, and technical implications must be carefully weighed to determine the long-term value of the project bearing in mind that in most cases, quarries are located in rural communities for which scarce resources. Human and financial resources would find better use in other development initiatives.

\section{Conclusion}

Environmental management of quarries requires site characterization, identifying sensitive areas. This rational operating plan respects the environment, a risk mitigation plan related to the operation, and a site redevelopment plan to rebalance the environment's ecological conditions. This management method is provided for in the text of the law, which also provides for control of the operation and rehabilitation of quarries.

Three types of activities can help reduce the impacts of exploiting AD quarries:

- The preservation of the most sensitive natural sites. (shorelines, river alluvium) by referring to the classification of sites according to environmental constraints, which imposes restrictions or even prohibitions for the most sensitive areas.

- The implementation of measures and processes to reduce the major impacts and reduce the nuisances generated by the activities. These measures concern the operation, rehabilitation or redevelopment, and the control and effective monitoring procedures to be implemented by operators and administrative authorities. - A rehabilitation plan for old abandoned quarries to secure and/or give the site another vocation (re-greening, the transformation of excavations into lagoon basins, etc.)

\section{Références}

1. M. OUADIA : Les formations plio-quaternaires dans le domaine mésétien occidental entre Casablanca et Safi: Géomorphologie, Sédimentologie, Paléoenvironnements quaternaires et Evolution actuelle. Thèse d'Etat es Sciences (1998). Univ. Mohammed V. Rabat, $319 \mathrm{p}$

2. A. Héquette et M.H. Ruz migration de cordons littoraux par processus de débordements de tempête dans le cadre d'une transgression marine, kvadehuk, péninsule de brôgger, spitsberg, Géographie physique et Quaternaire, 1986, vol. XL, n² 2, p. 197 206, 